\title{
Minimal climate change impacts on natural organic matter forecasted for a potable water supply in Ireland
}

\author{
Connie O'Driscoll a,d,* José L.J. Ledesma ${ }^{\mathrm{b}, * *}$, John Coll ${ }^{\mathrm{c}}$, John G. Murnane ${ }^{\mathrm{d}, \mathrm{g}}$, Paul Nolan ${ }^{\mathrm{e}}$, Eva M. Mockler ${ }^{\mathrm{f}}$, \\ Martyn N. Futter ${ }^{\mathrm{b}}$, Liwen W. Xiao ${ }^{\mathrm{a}, * *}$ \\ a Department of Civil, Structural and Environmental Engineering, TCD, Dublin, Ireland \\ b Department of Aquatic Sciences and Assessment, SLU, Uppsala, Sweden \\ c Irish Climate Analysis and Research Units, Department of Geography, NUI Maynooth, Maynooth, Co Kildare, Ireland \\ d Department of Civil Engineering, NUIG, Galway, Ireland \\ e Irish Centre for High End Computing (ICHEC), Research and Applications Division, Met Éireann, Dublin, Ireland \\ ${ }^{\mathrm{f}}$ UCD School of Civil Engineering, UCD, Dublin, Ireland \\ ${ }^{g}$ School of Engineering, University of Limerick, Ireland
}

\section{H I G H L I G H T S}

- Potential impacts of climate change on NOM were projected.

- Results show future behaviours are similar to current conditions.

- Projected increases are offset by parallel decreases in precipitation and flow.

\section{A R T I C L E I N F O}

\section{Article history:}

Received 22 December 2017

Received in revised form 19 February 2018

Accepted 20 February 2018

Available online $\mathrm{xxxx}$

Editor: D. Barcelo

\section{Keywords:}

Natural organic matter

Carbon cycle

Surface water

Climate change

INCA-C

Ireland
GRA P H ICA L A B STRACT

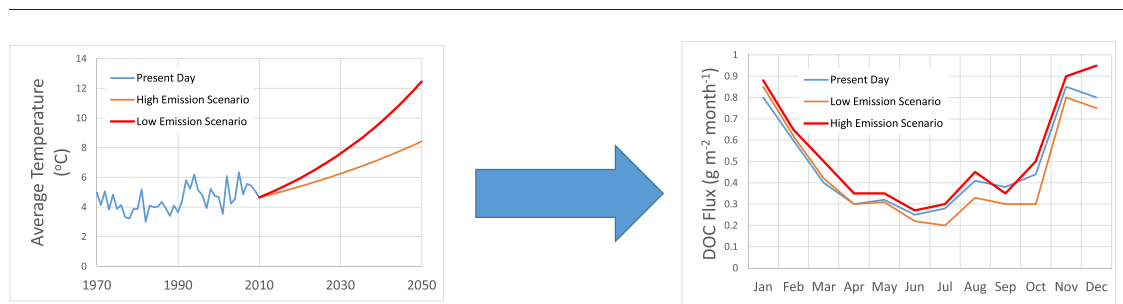

\section{A B S T R A C T}

Natural organic matter poses an increasing challenge to water managers because of its potential adverse impacts on water treatment and distribution, and subsequently human health. Projections were made of impacts of climate change on dissolved organic carbon (DOC) in the primarily agricultural Boyne catchment which is used as a potable water supply in Ireland. The results indicated that excluding a potential rise in extreme precipitation, future projected loads are not dissimilar to those observed under current conditions. This is because projected increases in DOC concentrations are offset by corresponding decreases in precipitation and hence river flow. However, the results presented assume no changes in land use and highlight the predicted increase in DOC loads from abstracted waters at water treatment plants.

(C) 2018 Published by Elsevier B.V.

\footnotetext{
* Correspondence to: C. O'Driscoll, Department of Civil Engineering, NUIG, Galway, Ireland.

** Corresponding authors.

E-mail addresses: odriscco@tcd.ie, connieodriscoll@gmail.com (C. O'Driscoll), jose.ledesma@slu.se (J.L.J. Ledesma), liwen.xiao@tcd.ie (L.W.Xiao).
}

\section{Introduction}

Declines in the quality of potable surface waters, including increasing concentrations of natural organic matter (NOM) have the potential to impact on human health and the costs of drinking water treatment (Whitehead et al., 2009; Delpla et al., 2009). NOM, which can be approximated and measured as dissolved organic carbon (DOC), are 
susceptible to higher concentrations as a consequence of extreme precipitation events in temperate ecoregions (Delpla et al., 2009).

Elevated DOC concentrations can affect the functioning and cost of water treatment processes (Eikebrokk et al., 2004), as DOC can increase mobility of contaminants and toxic compounds, and is a precursor for harmful disinfection by-products produced during chlorination including potentially carcinogenic trihalomethanes (THMs). Additionally, elevated DOC concentrations in drinking water supply systems can lead to increased problems with microbial growth and biofouling. Labile DOC (i.e. polysaccharides and proteins) can promote microbial growth in water distribution networks, providing habitats for potentially harmful microorganisms which are protected from disinfectants such as chlorine (Kilb et al., 2003). Thus, local and regional scale predictions of DOC concentrations in drinking water supplies are warranted so as to safely and economically manage water treatment and distribution.

Ireland has the highest reported THM exceedances in potable water across the European Union (EU) (O'Driscoll et al., 2018). In Ireland, most drinking water is abstracted from surface sources which are more susceptible to high DOC concentrations. Karst geology may further compromise many groundwater sources (Daly, 2009) as swallow holes and other surface karst features provide increased connectivity between surface water and groundwater. As is the case with other northern midhigh latitude areas (de Wit et al., 2016a), it is anticipated that climate change will also increase DOC in Irish surface waters (Naden et al., 2010).

Leaching of organic carbon from soils is considered to be the key contributor to DOC in surface waters (Hejzlar et al., 2003) with $2.9 \mathrm{Pg} \mathrm{C} \mathrm{yr}^{-1}$ reported to be mobilised (Regnier et al., 2013). Anthropogenic disturbance, i.e. deforestation, agricultural intensification, and wastewater discharge is believed to be responsible for up to 1.0 $\mathrm{Pg} \mathrm{C} \mathrm{yr}{ }^{-1}$ since the beginning of the industrial revolution (Regnier et al., 2013). Some degree of anthropogenic climate change is unavoidable; and while much effort has been given to quantitative assessment of water supply, relatively less is known about human induced climate change on the factors controlling organic carbon dynamics (Delpla et al., 2009). Both positive and negative effects of a changing climate on DOC leaching can be hypothesized. Warmer and wetter soils may support higher rates of biological activity and DOC production, while increased drought frequency and severity may suppress DOC production and intensify hydrophobicity (Moore et al., 2008).

Multiple DOC simulation models exist for both terrestrial and aquatic environments (summarised in de Wit et al., 2016a). The Integrated Catchments model for Carbon (INCA-C; Futter et al., 2007) has been used to simulate the effect of climatic, land use and acidificationrelated variables on DOC fluxes from soils to surface waters and under current and future conditions for a range of catchment sizes and across different land use categories in Fennoscandia and Canada (de Wit et al., 2016a).

INCA-C modelling of a forestry catchment in southern Finland has shown that (1) historical increases in DOC concentration can be attributed to declines in sulfate deposition and (2) future DOC increases are associated with a changing climate (Futter et al., 2009). Increased DOC concentrations have also been projected for a large, primarily agricultural catchment in Southern Ontario, Canada (Oni et al., 2012). Large seasonal variations in DOC concentrations associated with a shift of maximum summer temperatures towards winter and a longer persistence of elevated summertime DOC concentrations were observed in the same area (Oni et al., 2015a). Given the considerable uncertainties associated with the complexity of processes regulating soil carbon flux (de Wit et al., 2016a), we believe there is a pressing need for further impact studies which follow standardised protocols and allow for intercomparison of the effect of climate extremes on terrestrial carbon cycling (Frank et al., 2015). Such studies can also help in decision-making processes for current and future use of rivers for drinking water supply (Ledesma et al., 2012). The main objective of this study was to project potential future climatic impacts on flow and DOC concentrations and fluxes for a representative agricultural catchment (Boyne catchment, Fig. 1) which provides potable water to large supply zones in Ireland. INCA-C models were first used to simulate current DOC concentrations and fluxes. Downscaled temperature and precipitation outputs from two Regional Climate Models (RCMs) were then used to drive the INCA-C model.

\section{Methods}

\subsection{Study area}

The Boyne catchment $\left(2693 \mathrm{~km}^{2}\right)$ is located in east-central Ireland. On average, it receives $900 \mathrm{~mm}$ annual rainfall and has an average gradient of $1.24 \mathrm{~m} \mathrm{~km}^{-1}$ along its main channel length (113 km), which discharges to the Irish Sea (Fig. 1). The Boyne River drains the southern part of catchment and the Kells Blackwater River drains the northern part of the catchment. The confluence of the two tributaries is approximately $30 \mathrm{~km}$ west of the discharge point. The main anthropogenic pressures in the catchment are associated with diffuse pollution from agricultural runoff, point source effluent discharges from 21 Municipal Wastewater Treatment Plants (WWTP), and peat harvesting in the upper parts of the catchment. The Boyne catchment has a history of deteriorating water quality, the most prominent being eutrophication of lakes in the upper reaches of the Kells Blackwater (Toner et al., 2005).

Soils in the Southern and central parts of the catchment are dominated by grey brown podzols and gley soils with significant peat deposits, whereas soils in the north are more typically acid brown earths and gleys. Land use in the catchment has been characterized using the CORINE Land Cover Dataset 2012. Arable land used for crop cultivation accounts for $11 \%$ of the total area, and pasture is the accounts for a further $80 \%$. Forest, semi-natural areas, moors and heathland, and transitional woodland-scrub cover $3 \%$ of the catchment, while peat, urban areas and lakes account for the other 6\%. Catchment soils are not sensitive to acidification (Aherne et al., 2002).

\subsection{Model data}

Daily temperature and precipitation data were obtained from Mullingar and Kilskyre for 1st January 2005 to 30th April 2016 (Met Éireann, Fig. 1). Daily flows at Roughgrange $\left(2475 \mathrm{~km}^{2}\right)$, approximately $15 \mathrm{~km}$ upstream the main catchment outlet (Fig. 1), were obtained from the EPA (www.epa.ie/hydronet/\#07059) for the period 22nd December 2005 to 2nd February 2015. An on-line submersible spectrophotometer, spectro::lyser ${ }^{\mathrm{TM}}$ equipped with a $35 \mathrm{~mm}$ measuring cell (s::can Messtechnik), installed on the raw water abstraction point at the Staleen water treatment plant (the same location as for the flow measurements), was used to estimate daily DOC values for 7th September 2014 to 2nd December 2015. Daily time series of agricultural manure spreading, reported as $\mathrm{kg}$ DOC ha ${ }^{-1} \mathrm{day}^{-1}$ were generated based on typical manure concentrations in the area (Murnane et al., 2016) applied at rates permitted under current legislation (SI No. 31 of 2014).

\subsection{Hydrological modelling}

The Precipitation, Evapotranspiration and Runoff Simulator for Solute Transport (PERSiST) rainfall-runoff model (Futter et al., 2014) was used to generate daily stream flow, soil moisture deficit (SMD) and hydrologically effective rainfall (HER) datasets for use in INCA-C carbon simulations. The Boyne catchment was divided into 6 land use classes: pasture $(75 \%)$, agriculture $(13 \%)$, forest $(5 \%)$, peatland $(4 \%)$, urban (2\%), and lake (1\%). These proportions differ slightly from those of the whole catchment because simulations were performed only for the area draining Roughgrange (where flow and DOC measurements were taken), which is approximately $200 \mathrm{~km}^{2}$ smaller than the total Boyne catchment area. PERSiST was calibrated using long-term (December 2005-February 2015) observed stream flow at Roughgrange and 

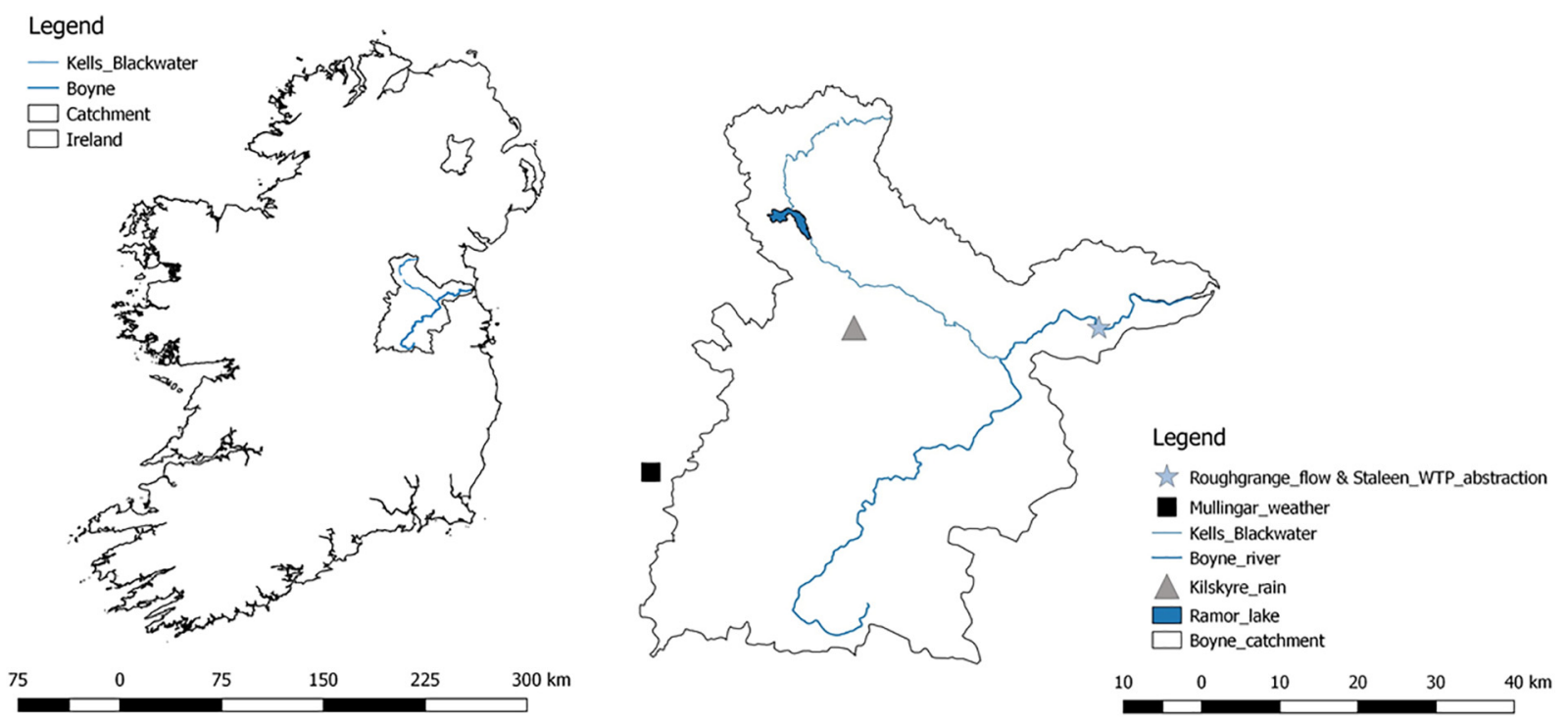

Fig. 1. Boyne catchment, Ireland, and temperature (Mullingar), rainfall (Kilskyre), and flow and DOC (Roughgrange) stations.

precipitation and temperature data obtained from the Kilskyre and Mullingar stations, respectively (Fig. 1). Simulations of present day flows were performed for the period where appropriate meteorological data were available (January 2005 to April 2016).

Manual calibration was first performed by fine tuning the parameters to minimise the difference between the simulated and observed runoff. Model performance was assessed using the Nash- Sutcliffe (NS) efficiency test (Nash and Sutcliffe, 1970) of observed and log-transformed flows. In order to assess parameter sensitivity and potentially improve model performance, a Monte Carlo (MC) analysis was performed, consisting of 100 iterations with 700 runs each. Model runs with better fits guided decision making about the upper and lower limits of each parameter for the next MC iteration. This process was repeated until no further improvement in the model N-S and $\log (\mathrm{N}-\mathrm{S})$ efficiencies was achieved.

\subsection{DOC modelling}

INCA-C requires daily outputs of HER and SMD from PERSiST in addition to daily precipitation and temperature time series to simulate DOC concentrations and fluxes (Futter et al., 2009). The same land use classes and simulation period (January 2005-April 2016) used in the PERSiST model were also applied for INCA-C, which was calibrated to the available DOC data (September 2014-December 2015). Initial catchment flow and DOC values were used $\left(70 \mathrm{~m}^{3} \mathrm{~s}^{-1}\right.$ and $7 \mathrm{mg} \mathrm{L}^{-1}$ respectively) for 1 st of January 2005, based on average known conditions. The model set up included a constant effluent from the 21 WWTPs calculated based on daily discharge flows from the facilities. DOC concentrations here were set to $5 \mathrm{mg} \mathrm{L}^{-1}$ based on average DOC concentrations in their outlet waters. Initial conditions on soil organic carbon (SOC) pools and DOC soil solution concentrations for the different land use types were estimated from data in Wellock et al. (2011a, 2011b) (Supplement Table S1). Upper soil horizons contain higher DOC and SOC concentrations than lower soil horizons, while peat and forest soils show greater values than pasture and agricultural soils.

A manual calibration was carried out to achieve a good approximation to the observed values prior to applying MC simulations. The calibration strategy first established operational values for the sensitive hydrological parameters, soil volumes, and residence times until simulated flow was in the range of the PERSiST simulation and simulated DOC was in the range of the observed values. On achieving an acceptable fit to observed flows, hydrological parameters were fixed.
Subsequently, the parameters describing carbon transformations in the soil were adjusted.

The MC strategy described in Futter et al. (2014) was used for an exploration of the INCA-C parameter space. During the MC analysis, 100 iterations with 500 runs each were performed. The initial parameter boundaries were defined as $\pm 20 \%$ of the parameter values from the best performing manual calibration. After each iteration of the MC analysis, parameter sensitivity was assessed using the 100 best performing parameter sets, which were defined by ranking the N-S statistics comparing modelled and observed DOC. The analysis compared the cumulative parameter distributions derived from the best performing parameter sets to rectangular distributions, and if non-rectangular, the parameter was sensitive and the parameter range adjusted prior to the next MC iteration. This routine terminated when the MC analysis failed to provide any improvement in $\mathrm{N}-\mathrm{S}$ values over the preceding set of model runs. A final manual tuning of the sensitive parameters was carried out to correct the major mismatches and to improve the model efficiency.

Uncertainty estimates for the final model predictions were generated by assuming both that INCA could be treated in an analogous manner to a high-dimension non-linear regression and that standard methods for generating confidence intervals (e.g. Sokal and Rohlf, 1969) could be employed.

\subsection{Regional climate modelling and future DOC projections}

Global (GCMs) and Regional Climate Models (RCMs) simulate the potential impacts of increasing greenhouse gas concentrations. Local changes in precipitation and temperature are strongly associated with local geography and topography and are typically not adequately represented in GCM outputs due to e.g. model grid resolution (Coll, 2010). Limitations associated with GCM projections can be partially addressed through the use of RCMs, which simulate some topographical effects with a boundary size of $\sim 50 \mathrm{~km}$ Nolan (2016). Representative Concentration Pathways (RCPs) simulate climate change associated with changes in land use and global emissions of greenhouse gasses (Moss et al., 2010). Projections of future meteorologic conditions were generated by downscaling the EC-Earth consortium GCM to the locations of the Mullingar and Kilskyre Met Éireann stations (Fig. 1) using both the COSMO-CLM RCM (version 4.0) with a grid spacing of $4 \mathrm{~km}$, and the WRF RCM with a grid spacing of $6 \mathrm{~km}$ (Nolan, 2016). To account for some of the uncertainty arising from the estimation of future global emission of greenhouse gasses, two IPCC RCP (4.5 and 8.5) emission 
scenarios were used to simulate the future climate in this study. Projections of future climate were evaluated by comparing each of the present-day datasets with the corresponding future dataset for each simulation within the same group and realisation (Table 1).

Daily totals of precipitation $(\mathrm{mm})$ and mean temperatures $\left({ }^{\circ} \mathrm{C}\right)$ were interpolated for the Kilskyre and Mullingar Met Éireann stations for a baseline control (1981-2009) and a future period (2031-2059). These datasets were employed to force the calibrated PERSiST model so as to obtain the four output time series - precipitation, temperature, soil moisture deficits, and hydrologically effective rainfall needed to run INCA-C. INCA-C was then run using these simulate time series to generate new simulations for flow and DOC concentrations and fluxes for Roughgrange.

\section{Results}

3.1. Observed climate and catchment flow and DOC regimes for the model calibration periods

Mean annual temperature between 2005 and $2015\left(9.3^{\circ} \mathrm{C}\right.$ ) varied between $8.2{ }^{\circ} \mathrm{C}$ and $9.9^{\circ} \mathrm{C}$ (Supplement). The lowest and highest average temperatures for the non-growing season (Nov-Mar) were $2.4^{\circ} \mathrm{C}$ in 2010 and $6.3^{\circ} \mathrm{C}$ in 2007 respectively, whereas the lowest and highest average growing season temperatures (Apr-Oct) were $11.2^{\circ} \mathrm{C}$ and 12.9 ${ }^{\circ} \mathrm{C}$ in 2015 and 2006 respectively. December was the coldest month (4.6 $\left.\pm 2.3^{\circ} \mathrm{C}\right)$ and July the warmest $\left(15.0 \pm 1.3^{\circ} \mathrm{C}\right)$. Yearly precipitation ranged from 773 to $1120 \mathrm{~mm}$ with an average of $993 \mathrm{~mm}$ with typically lower amounts from February to June and higher values in November and December.

Measured discharge (December 2005-February 2015) ranged from average high flows $\left(Q_{05}\right)$ of $113.4 \mathrm{~m}^{3} \mathrm{~s}^{-1}$ to average low flows $\left(\mathrm{Q}_{95}\right)$ of $8.4 \mathrm{~m}^{3} \mathrm{~s}^{-1}$ (Fig. 2). Average daily flows were highest in January $\left(75.95 \mathrm{~m}^{3} \mathrm{~s}^{-1}\right)$ and lowest in June $\left(12.85 \mathrm{~m}^{3} \mathrm{~s}^{-1}\right)$ during the observed period.

Average DOC concentrations were $8.2 \mathrm{mg} \mathrm{L}^{-1}$, with minimum and maximum values of 5.7 and $13.4 \mathrm{mg} \mathrm{L}^{-1}$ respectively between September 2014 and December 2015. DOC concentrations showed a seasonal pattern with highest values occurring during autumnal flushing between November and January (Fig. 3). Episodic concentration peaks can be attributed to rainfall events (Ryder et al., 2014).

\subsection{Model-calibrated flow and DOC}

Calibration results from the INCA-C model resulted in credible simulations for both modelled flow $\left(r^{2}=0.80, N-S=0.75\right.$, Fig. 2) and modelled DOC $\left(r^{2}=0.74, N-S=0.73\right.$, Fig. 3$)$. Simulated flow was effectively equivalent between PERSiST and INCA-C. The most sensitive parameters $(p<0.01)$ identified by the PERSiST MC analysis included the runoff time constant in the lower soil layer and the 'flow velocity exponent' which controls water residence times in the streams. The most sensitive parameters $(\mathrm{p}<0.01)$ identified by the INCA-C MC analysis also included the lower soil layer runoff time constant and, the flow

Table 1

Details of the ensemble Regional Climate Model (RCM) simulations.

\begin{tabular}{llllll}
\hline RCM & GCM & $\begin{array}{l}\text { Scenario } \\
\text { (realisations) }\end{array}$ & $\begin{array}{l}\text { Climate } \\
\text { projections }\end{array}$ & $\begin{array}{l}\text { Time } \\
\text { period }\end{array}$ & $\begin{array}{l}\text { Grid } \\
\text { spacing }\end{array}$ \\
\hline COSMO-CLM & EC-Earth & Reference (3) & - & $1981-2009$ & $4 \mathrm{~km}$ \\
COSMO-CLM & EC-Earth & RCP 4.5 (3) & 3 & $2031-2059$ & $4 \mathrm{~km}$ \\
COSMO-CLM & EC-Earth & RCP 8.5 (3) & 3 & $2031-2059$ & $4 \mathrm{~km}$ \\
WRF & EC-Earth & Reference (3) & - & $1981-2009$ & $6 \mathrm{~km}$ \\
WRF & EC-Earth & RCP 4.5 (3) & 3 & $2031-2059$ & $6 \mathrm{~km}$ \\
WRF & EC-Earth & RCP 8.5 (3) & 3 & $2031-2059$ & $6 \mathrm{~km}$ \\
\hline
\end{tabular}

velocity exponent in the stream velocity equation, base flow index (a measure of the fraction of water routed from upper to lower soil boxes), plus the 'upper layer fast pool fraction' (fraction of the total SOC in the upper layer that is easily leachable), and the 'response to soil temperature variation of $10^{\circ} \mathrm{C}$ ' (representing the increase in biological production rate with increasing soil temperature).

Overall, INCA-C reproduced daily flows accurately, with a few overestimations for summer low flows (Fig. 2). There was a strong seasonal signal in both observed and simulated discharge, i.e. highest flows in winter period and lowest flows in spring and summer. Mean monthly flows were well captured by the model with some overestimations in summer and early autumn (data not shown).

Mean monthly simulated DOC concentrations (January 2005-April 2016) averaged $8.4 \mathrm{mg} \mathrm{L}^{-1}$ and demonstrated seasonality ranging from $6.6 \mathrm{mg} \mathrm{L}^{-1}$ in June to $10.9 \mathrm{mg} \mathrm{L}^{-1}$ in November. The seasonal DOC pattern for the calibration period (September 2014-December 2015) fitted the overall simulation period pattern and both INCA-C and observed DOC had very good correspondence (Fig. 3). Daily DOC observations were also very well captured by the model. However, while the timing was correct there was a tendency to underestimate some of the peaks.

The simulated daily DOC export pattern matched the observed trend in flow and DOC. In DOC export increased, similarly to DOC concentrations. Simulated average yearly DOC export between 2005 and 2015 was $5.8 \pm 1.3 \mathrm{~g} \mathrm{C} \mathrm{m}^{-2}$ year $^{-1}$ (maximum: $7.8 \mathrm{~g} \mathrm{C} \mathrm{m}^{-2}$ in 2008; minimum: $3.7 \mathrm{~g} \mathrm{C} \mathrm{m}^{-2}$ in 2005 (supplement)).

\subsection{Projected future climate}

Results of the 12 downscaled RCM experiments project warmer $\left(+1.1^{\circ} \mathrm{C}\right.$ average difference) conditions in 2031-2059 compared to present day INCA-C simulated values. Monthly average temperatures increase in all cases with little variation between WRF and COSMO (below $0.1^{\circ} \mathrm{C}$ ), RCP emission scenarios, and realisations within RCPs (Fig. 4a and b). Taking into account all scenarios, annual total precipitation is projected to decrease an average of $6 \%$ in the future. Results indicate decreased monthly precipitation in spring through to late summer, with larger decreases associated with the WRF precipitation projections (9\%) compared to COSMO (4\%) for the corresponding scenarios (Fig. 4c and $\mathrm{d}$ ). While the number of precipitation extremes projected by WRF are similar to the present day number, the COSMO RCM projects a higher potential frequency for these events (Fig. $5 \mathrm{a}$ and b), e.g. 20 versus 13 events larger than $40 \mathrm{~mm}$ for the future COSMO high emission scenario (2031-2059) compared to the COSMO baseline scenario (19812009), respectively.

\subsection{Model-simulated flow and DOC with projected future climate}

Average monthly flows are projected to be lower in 2031-2059 compared to the present day throughout the year (Fig. 6). These reductions are more pronounced than the decreases in precipitation, and are associated with a projected increase in future evapotranspiration. Considering all scenarios and realisations, highest flows in January are projected to decrease from 77.3 to $71.3 \mathrm{~m}^{3} \mathrm{~s}^{-1}$ and lowest flows from 32.1 in June in the present day to $24.8 \mathrm{~m}^{3} \mathrm{~s}^{-1}$ in July in the future period (2031-2059).

Applying the downscaled projections results in greater average yearly DOC concentration from 8.5 in the present day to $9.3 \mathrm{mg} \mathrm{L}^{-1}$ in the future, considering all scenarios and realisations. Mean monthly DOC concentrations in the future showed strong seasonality varying from $7.5 \mathrm{mg} \mathrm{L}^{-1}$ in June to $11.6 \mathrm{mg} \mathrm{L}^{-1}$ in November (Fig. 6).

Future DOC fluxes will tend to be higher in winter and spring (DecMay), and lower in summer and autumn (June-Oct) compared to the present day simulation according to the model simulations (Fig. 6) resulting in a future mean annual DOC flux similar to present day flux. 


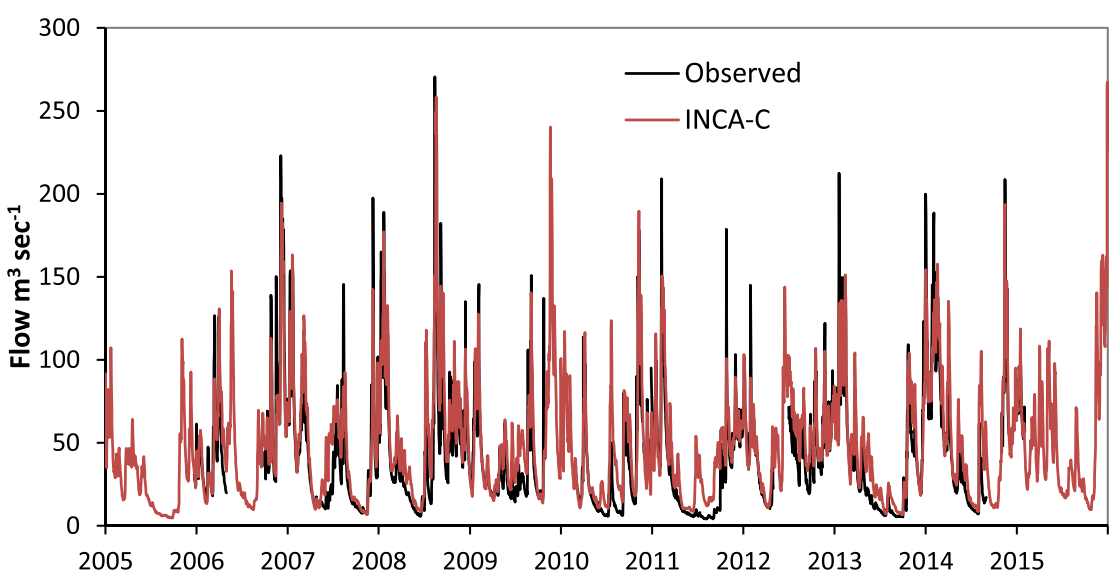

Fig. 2. Daily observed and simulated flow in the Boyne catchment.

\section{Discussion}

Observed DOC concentrations from Roughgrange fluctuated between 5.7 and $13.4 \mathrm{mg} \mathrm{L}^{-1}$, values that are comparable to recent studies of Irish stream DOC concentrations (Liu et al., 2014; Ryder et al., 2014). Seasonality of DOC concentrations has been linked to air temperatures (Koehler et al., 2009), suggesting that cool winters suppress biological production whereas spikes in DOC concentration in Autumn are a consequence of flushing of material produced during summer as well as DOC production from e.g. senescing vegetation after the end of the growing period (Liu et al., 2014). Patterns in soil temperature, discharge and rainfall accounted for $60 \%$ of the variation in DOC in a forested peat catchment in Ireland (Ryder et al., 2014). Soil temperature and hydrology also appear to drive temporal patters in DOC concentration in the agricultural catchment of the present study, as indicated by the sensitivity of some of the parameters in the model. These parameters include the soil time constant in the lower soil layer (a measure of timing of recession of the hydrograph), and the BFI representing the fraction of water that moves vertically through the soil, suggesting that riverine DOC concentrations are most sensitive to hydrology. Other significant parameters were, the fraction of the total SOC in the upper layer belonging to an easily leachable pool, and a parameter controlling process rate response changes in soil temperature, suggesting that riverine DOC concentrations follow soil temperature patterns that enhance biological production and are likely limited by the exhaustion of an easily leachable C pool (de Wit et al., 2016a).

Present day simulated average yearly DOC export from the Boyne catchment $\left(5.8 \pm 1.3 \mathrm{~g} \mathrm{C} \mathrm{m}^{-2}\right.$ year $\left.^{-1}\right)$ falls in the lower spectrum of values reported for peat catchments (Barry et al., 2016; de Wit et al., 2016b). However, the Boyne catchment has approximately $4 \%$ peatland and therefore with respect to agricultural catchments falls in the higher spectrum of values reported (Kronholm and Capel, 2012). The simulated daily DOC export pattern was strongly linked to patterns in discharge, as reported for forest catchments (Ledesma et al., 2012). Years with higher precipitation (2008, 2012, 2014 and 2015) showed greater DOC export. The lowest DOC value reported during our study period occurred during summer after a dry period. Low DOC production in soils during drought has been attributed to a decrease in microbial activity and organic carbon solubility due to increased acidity following oxidation of organic sulfur to sulfate when oxygen availability increases (Kalbitz et al., 2000). A summer DOC concentration peak also occurred following a period of high discharge suggesting other factors besides senescing vegetation are responsible for DOC production in this catchment, namely hydrological activation of upper organic-rich soil layers (Ledesma et al., 2015).

INCA-C reproduced the observed hydrological patterns in the Boyne Catchment with model goodness of fit $\left(r^{2}=0.80, N-S=0.75\right)$ showing comparable accuracies with those reported in other INCA-C studies (Futter et al., 2014; Oni et al., 2015b; de Wit et al., 2016a). The model goodness of fit for DOC was high in comparison to some studies $\left(\mathrm{r}^{2}=\right.$ $0.74, \mathrm{~N}-\mathrm{S}=0.73$ ) but not as high as is common in empirical studies such as e.g. de Wit et al. (2016b), who measured ascending concentrations at 474 sites in Norway, Sweden and Finland between 1990 and 2013.

This study is one of the first to use continuous daily DOC data for model calibration. High resolution continuous monitoring is important to accurately capture DOC trends in peak and base flow conditions (Tunaley et al., 2016). Having more data points implies that a wider

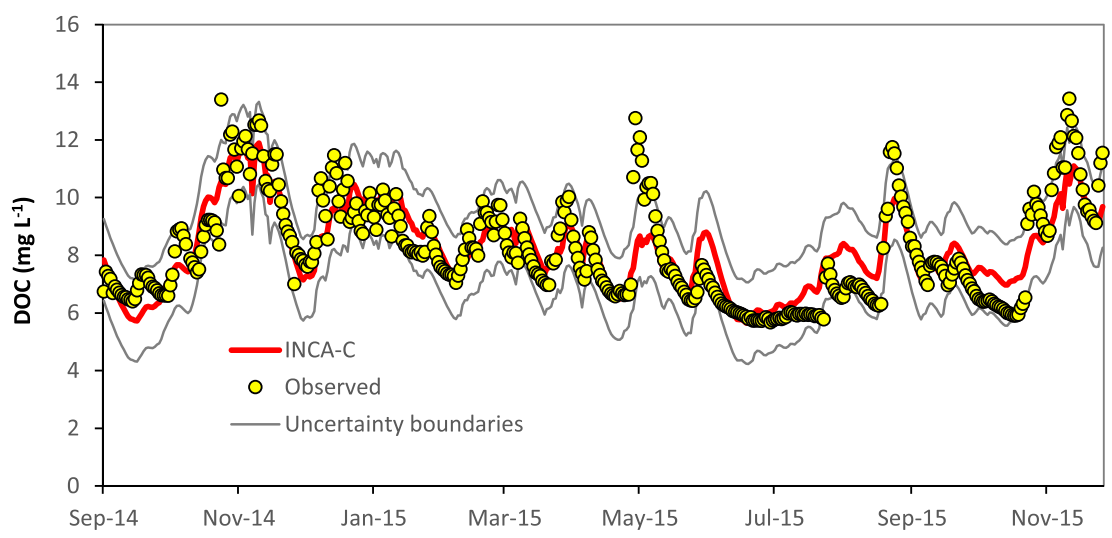

Fig. 3. Daily observed and simulated DOC concentrations in the Boyne Catchment including uncertainty boundaries. 
a)

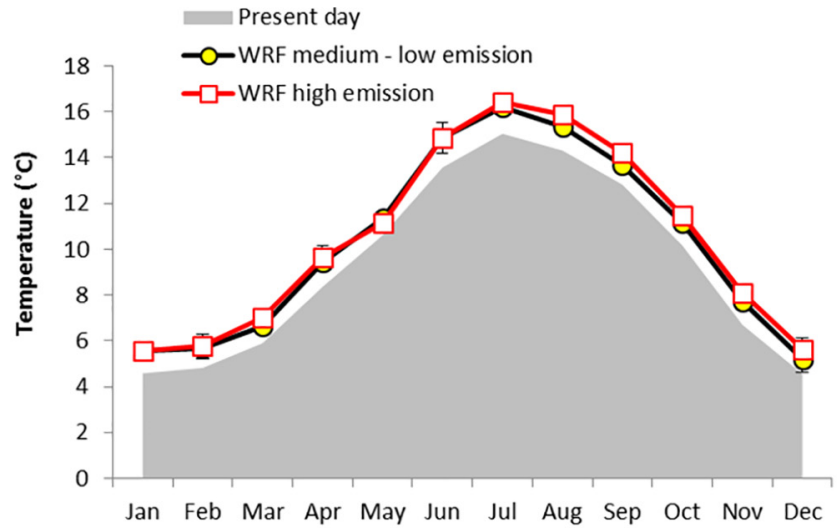

b)

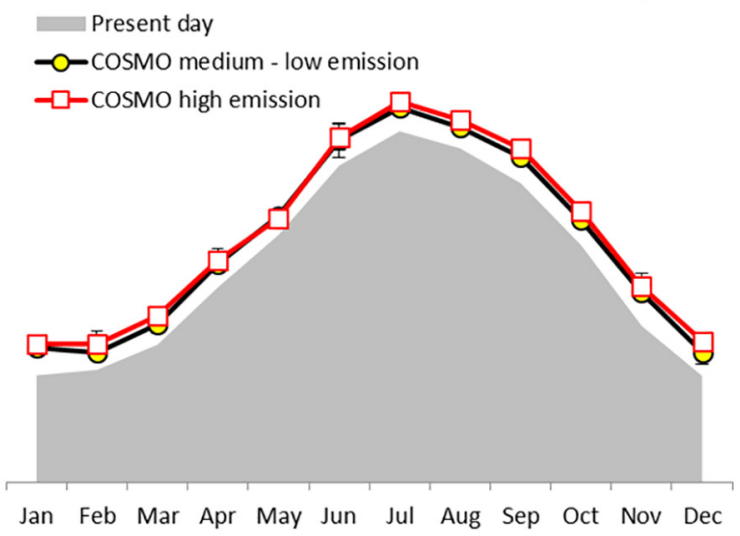

c)

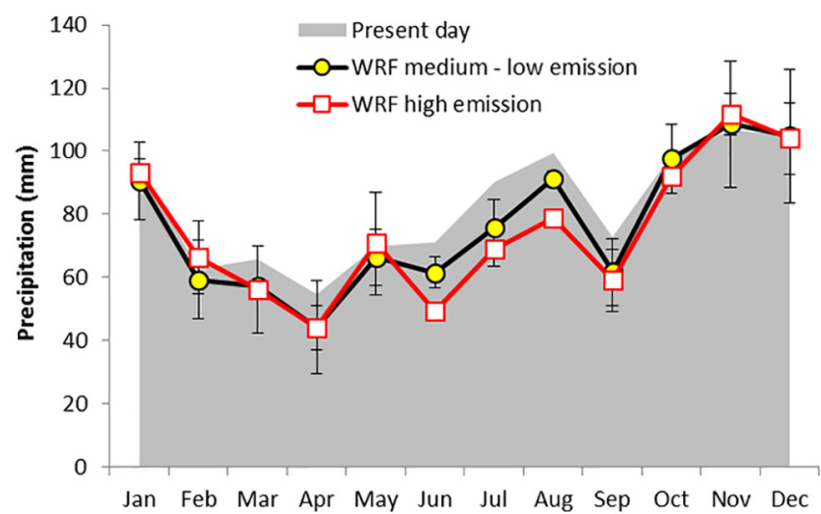

d)

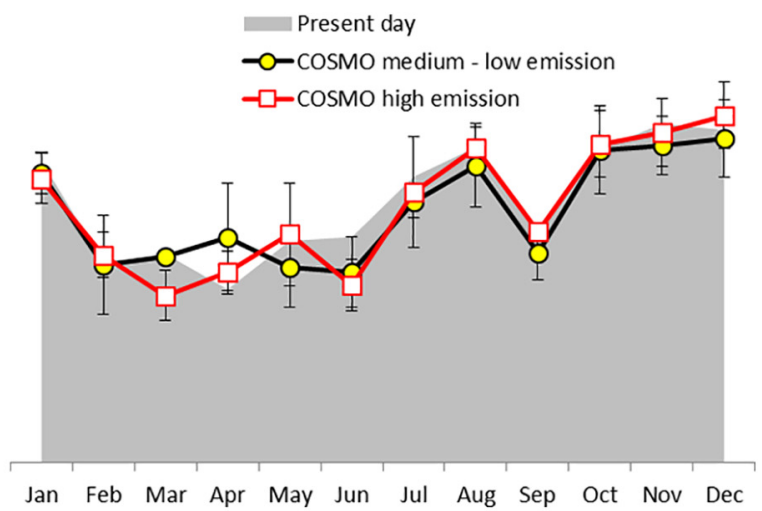

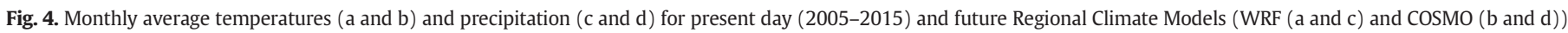
scenarios (2031-2059) in the Boyne Catchment. Error bars are standard deviations of the three realisations of each scenario.

range of environmental conditions are included which, a priori, would be harder to capture in a single model parameter set. However, the high model performance obtained here suggests that (1) INCA-C can accurately reproduce a broad spectrum of daily DOC values and (2) high frequency monitoring data (e.g. from sensors) could (or even should) be routinely incorporated into model applications. For example, high resolution data is critical to accurately predict high DOC values that occur under high discharge conditions. Considering daily DOC values as we did here we have omitted the risk of missing such events (Ledesma et al., 2012), although the model did not capture the magnitude of all of these peaks. This error could lead to errors in estimation

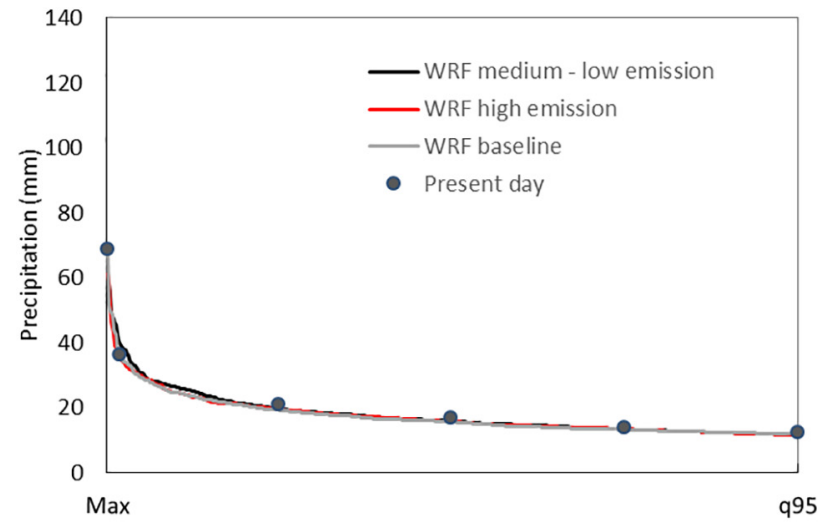

of DOC fluxes of approximately 30\% (Ledesma et al., 2012). This could become more relevant in the future if more extreme precipitation events occur, as projected by the COSMO model. The quality and representativeness of input and calibration data, together with good model representation of processes driving flow and DOC in the Boyne catchment are likely to have been important factors for the successful model simulation presented here. Thus the simulations were capable of accurately reproducing short term variability in daily DOC time series. Furthermore, the best parameter sets obtained during calibration reproduced flow and DOC concentrations over a wide range of different environmental conditions, suggesting that they are robust for future

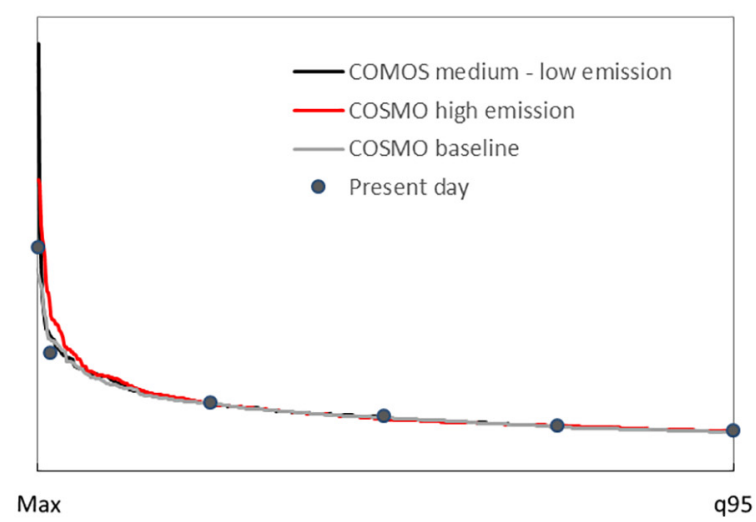

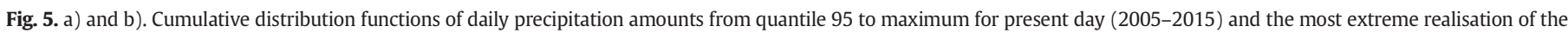
Regional Climate Models (WRF (a) and COSMO (b)) scenarios (2031-2059), including baseline scenario (1981-2009), in the Boyne Catchment. 
a)

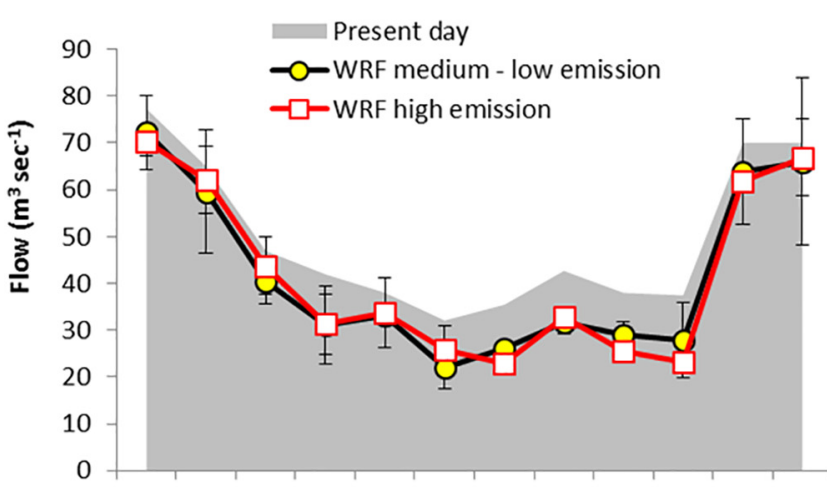

Jan Feb Mar Apr May Jun Jul Aug Sep Oct Nov Dec

b)

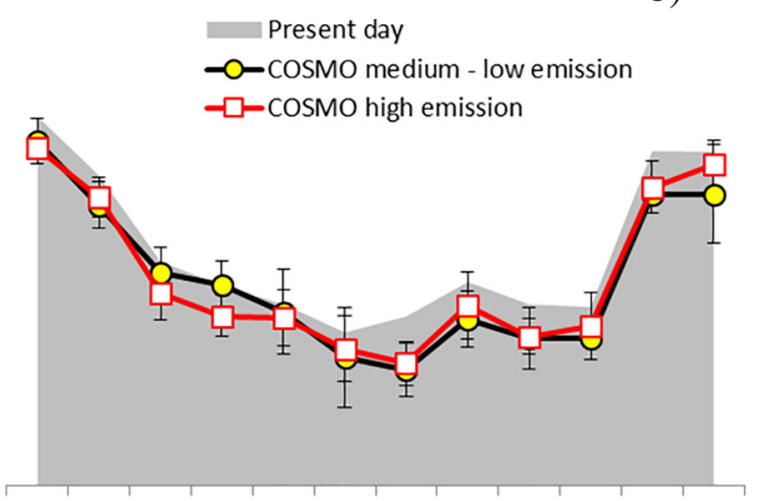

Jan Feb Mar Apr May Jun Jul Aug Sep Oct Nov Dec

d)
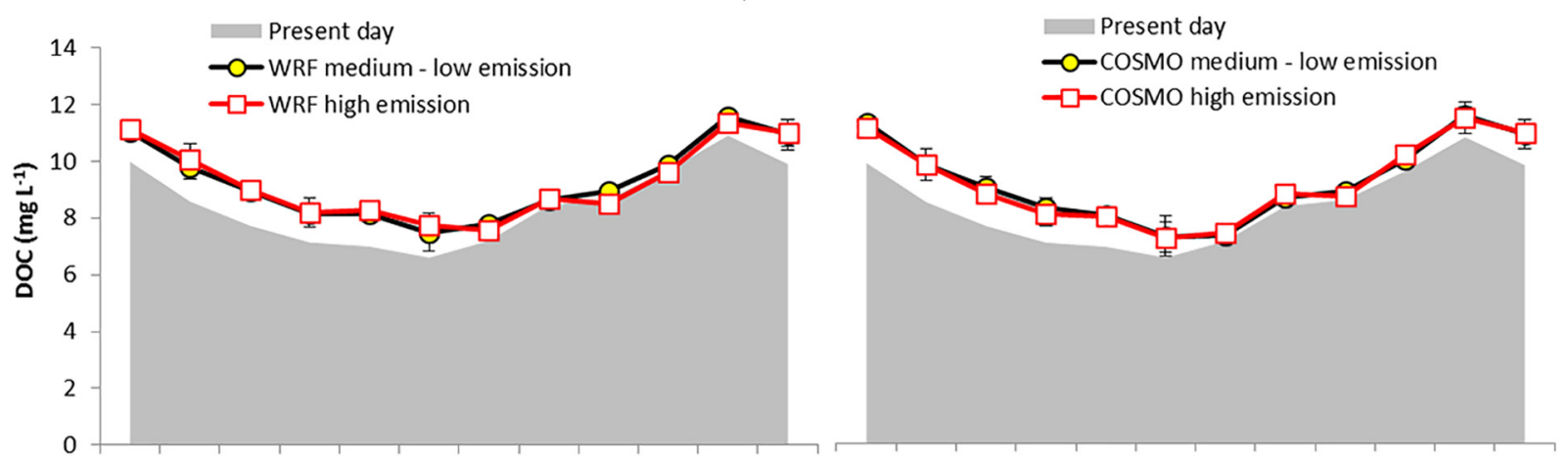

Jan Feb Mar Apr May Jun Jul Aug Sep Oct Nov Dec

Jan Feb Mar Apr May Jun Jul Aug Sep Oct Nov Dec

e)

f)
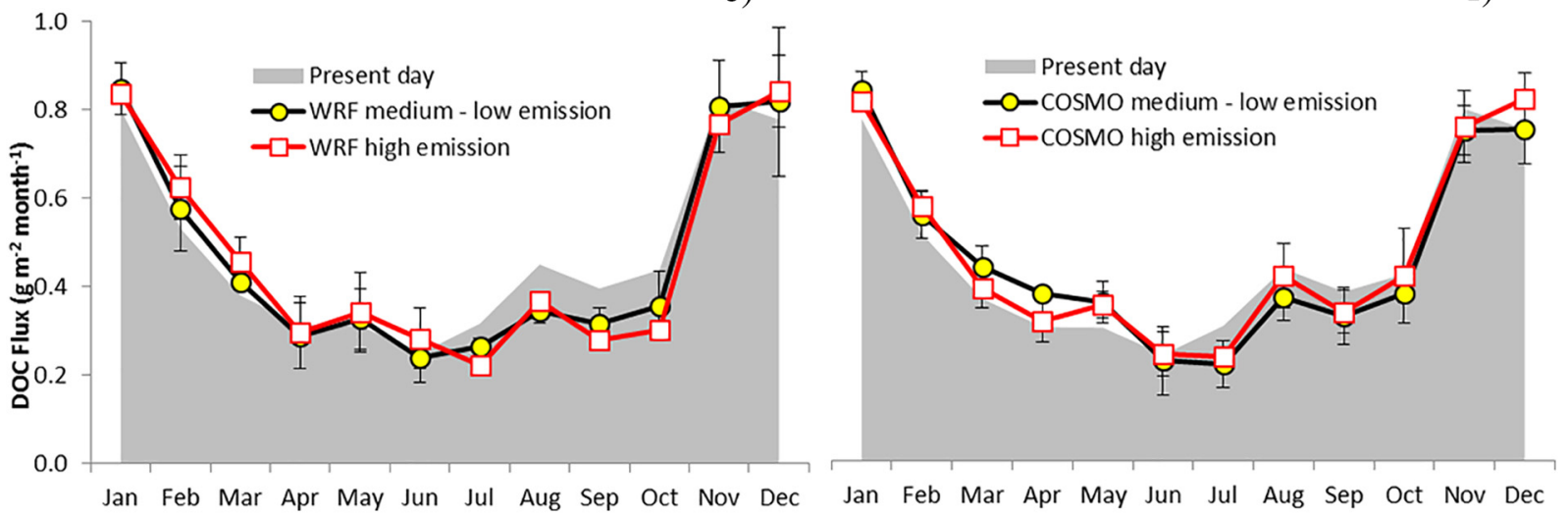

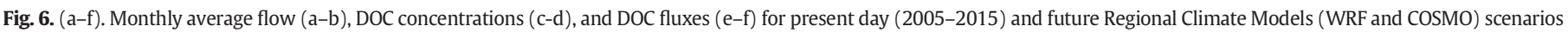
(2031-2059) in the Boyne Catchment. Error bars are standard deviations of the three realisations of each scenario.

simulations spanning a potentially wide range of conditions (Moss, 2007).

Susceptibility of peatland and forest catchments to climate change impacts is well studied, but there have been limited assessments of potential future DOC concentration in surface waters of predominantly agricultural catchments (but see Hejzlar et al., 2003; Oni et al., 2012). Climate change studies in this context are more often performed in relation to nutrients (Couture et al., 2014).

Average yearly temperatures are projected to rise in the Boyne Catchment by $1-1.1{ }^{\circ} \mathrm{C}$. These changes represent the largest so far projected to occur for the country (Nolan, 2016). Total annual precipitation is projected to decrease slightly with results suggesting a moderate decrease in projected monthly averages in spring through to late summer. However, frequencies of heavy precipitation events are forecasted to increase according to COSMO projections. These events are the primary cause for "risk" situations with regard to trends in the degradation of drinking water quality (Delpla et al., 2009). Rising temperatures will likely cause an increase in evapotranspiration that coinciding with decreased precipitation, will culminate in reduced flows. DOC mean monthly concentrations show an overall increase. Mean annual DOC export showed no change in the future with any of the climate and emission scenarios because the increase in DOC concentrations is counterbalanced by the decrease in flow, which is the driver of DOC fluxes. To better inform practice for water managers the concentration of DOC should be given more weight as the water treatment plant abstracts the same amount of water from year to year, therefore DOC loads within treatment plants are set to increase with increasing concentrations. 
Climate impact assessment studies, such as the one presented here, can be interpreted in quantitative or qualitative terms (van Vuuren et al., 2008). Fully probabilistic quantitative analyses with extensive evaluation of different sources of uncertainty e.g. parameter sensitivity and their consequences for model projections have the potential to present an unrealistically precise view of possible future conditions. The present study based on a single impact model and four future climate realisations considers a restricted subset of possible sources of uncertainty. Thus, it would be more appropriate to interpret the results as qualitative representations of a subset of all possible futures. Qualitative alternative scenarios based on internally consistent narratives, or "storylines" are based in part on the premise that future conditions will vary over an unknown range. Despite the heterogeneity projected in possible future temperature and precipitation patterns as compared with present day conditions, the simulated catchment DOC load response was insensitive to climate change. With the exception of a potential increase in extreme precipitation, the range of projected future behaviours are not dissimilar to those observed under current conditions. However, the results presented here assume no changes in land use.

When compared to uncertainties in future DOC loads, the uncertainty in possible future land use and land management is likely to have a larger effect on the range of possible futures for water quality in agricultural catchments. Socio-economic changes have the potential to have major but unforeseen effects on land cover or land management (Holman et al., 2017). For example, before the economic crash in 2008, Rounsevell et al. (2006) projected a wide range of possible land use futures for Irish agriculture, ranging from "business as usual" to a significant abandonment of agricultural land. However, the immediate focus ten years on is for agricultural expansion and intensification (EPA, 2016). Bord Na Móna, an Irish semi-state company, owns 7.5\% of Irish bogs, and actively harvests $\sim 3 \%$ of all Irish bogs. In a recent statement Bord na Móna announced the 'biggest change' of Irelands land use in modern history, that after 2030 the company will no longer harvest energy peat and will rehabilitate tens of thousands of acres of Irish bogs to new biodiverse habitats. It is believed that these degraded habitats will be less resilient to the potential impacts of climate change adaptation than their undisturbed active bog counterparts (Coll et al., 2009).

Changing patterns of land use or land management have the potential to significantly change possible future fluxes of DOC, and such changes are not included in the simulations presented here. While there are potentially larger uncertainties associated with land use change than with climate change, the modelling exercise presented here can provide plausible storylines relevant for decision-making, for example management of water treatment plants. Generation of storylines with partial accounting of uncertainty by combining moderate (e.g. RCP-4.5) and extreme (RCP-8.5) climate scenarios has been employed in ecological studies to contribute to a dialogue about possible futures (Cremona et al., 2017). Similar results have been presented elsewhere for boreal waters (Oni et al., 2015b). While Cremona et al. (2017) and Oni et al. (2015b) do not provide probabilistic assessments of future conditions, their qualitative storylines are more representative of the true, unknown range of uncertainty in possible future conditions. Interpreting the results presented here as part of a qualitative storyline about possible futures offers water treatment plant operators and society a starting point for any dialogue about the consequences of climate change for drinking water supply.

The Kells Blackwater, a tributary of the Boyne has a long history of eutrophication and 'poor' water quality status. Understanding catchment processes can help alleviate drinking water treatment costs and will form part of the engineered solution to adapting infrastructure to cope with future climate changes (Grayson et al., 2012). In a national assessment of THM exceedances in Irish drinking waters catchments with 'higher peat soil and agricultural land use' were a positive determinant of THM concentrations in treated water (O'Driscoll et al., 2018). Furthermore, in terms of quality NOM characteristic of reprocessed humic organic matter was the prominent component remaining following drinking water treatment. This current study shows that NOM quantity can be modelled with continuous data. Further work should examine the possibilities of modelling NOM quality subject to projected intensification of agriculture.

\section{Conclusions}

As far as we are aware this is the first study which employs routine monitoring data from a water treatment plant for a large predominantly agricultural catchment to simulate the effects of changing climate on raw drinking water DOC concentrations. Soil temperature and discharge appeared to drive the temporal patterns in DOC concentrations. Export for this catchment while lower than that reported for Irish peat catchments is higher than that reported for agricultural catchments elsewhere.

Simulations were capable of accurately reproducing short term variability in daily DOC time series. Average yearly temperatures are set to increase by $1-1.1^{\circ} \mathrm{C}$. Total annual precipitation is set to decrease however frequencies of heavy precipitation are set to increase and it is these events that cause the greatest problem for water managers. Furthermore, DOC export showed no change owing to the decrease in flows counteracting the increase in DOC concentrations however this will not benefit water managers in the future as DOC loads within treatment plants are set to increase with increasing concentrations.

The results highlight the un-explored resource of high-resolution routine water treatment plant monitoring data together with routine catchment monitoring data and coupled with high-resolution climate models to present internally consistent, management-relevant storylines about possible climate change effects on future NOM increases.

\section{Acknowledgements}

Our study was funded by the Irish Environmental Protection Agency (EPA) under the Water - EPA Research Strategy 2014-2020 program (grant number 2013-W-MS-14). JC also acknowledges funding provided by the EPA under project 2012-CCRP-FS.11. Sincere thanks are extended to Local Authorities for allowing site access.

\section{Appendix A. Supplementary data}

Supplementary data to this article can be found online at https://doi. org/10.1016/j.scitotenv.2018.02.248.

\section{References}

Aherne, J., Kelly-Quinn, M., Farrell, E.P., 2002. A survey of lakes in the Republic of Ireland: hydrochemical characteristics and acid sensitivity. Ambio 31, 452-459.

Barry, C.D., Renou-Wilson, F., Wilson, D., Müller, C., Foy, R.H., 2016. Magnitude, form and bioavailability of fluvial carbon exports from Irish organic soils under pasture. Aquat. Sci. https://doi.org/10.1007/s00027-015-0464-x.

Coll, J., 2010. Climate change and Europe's mountains. In: Price, M.F. (Ed.), Europe's ecological backbone: recognising the true value of our mountains. EEA Rep No. 6/2010. European Environment Agency, Copenhagen, pp. 74-84.

Coll, J., Maguire, C., Sweeney, J., 2009. Biodiversity and climate change in Ireland. Briefing Paper for Comhar SDC, Dublin, p. 85.

Couture, R.M., Tominaga, K., Starrfelt, J., Moe, S.J., Kaste, O., Wright, R.F., 2014. Modelling phosphorus loading and algal blooms in a Nordic agricultural catchment-lake system under changing land-use and climate. Environ. Sci.: Processes Impacts 16, 1588-1599.

Cremona, F., Vilbaste, S., Couture, R.M., Noges, P., Noges, T., 2017. Is the future of large shallow lakes blue-green? Comparing the response of a catchment-lake mode chain to climate predictions. Clim. Chang. 141, 347-361.

Daly, D., 2009. Groundwater the "hidden resource". Biol. Environ. Proc. R. Ir. Acad. 109B (3), 221-236.

de Wit, H.A., Ledesma, J.L.., Futter, M.N., 2016a. Aquatic DOC export from subarctic Atlantic blanket bog in Norway is controlled by seasalt deposition, temperature and precipitation. Biogeochemistry 127, 305-321.

de Wit, H.A., Valinia, S., Weyhenmeyer, G.A., Futter, M.N., Kortelainen, P., Austnes, K. Hessen, D.O., Raike, A., Laudon, H., Vuorenmaa, J., 2016b. Current browning of surface 
waters will be further promoted by wetter climate. Environ. Sci. Technol. Lett. 3 , 430-435.

Delpla, I., Jung, A.-V., Baures, E., Clement, M., Thomas, O., 2009. Impacts of climate change on surface water quality in relation to drinking water production. Environ. Int. 35, $1225-1233$.

Eikebrokk, B., Vogt, R.D., Liltved, H., 2004. NOM increase in Northern European source waters: discussion of possible causes and impacts on coagulation/contact filtration processes. In: Newcombe, G., Ho, L. (Eds.), Natural Organic Material Research: Innovations and Applications for Drinking Water, pp. 47-54.

Environmental Protection Agency, 2016. State of the environment report. EPA Publication, Wexford http://www.epa.ie/pubs/reports/indicators/irelandsenvironment 2016.html, Accessed date: 10 September 2017.

Frank, D., Reichstein, M., Bahn, M., Thonicke, K., Frank, D., Mahecha, M., Smith, P., Van Der Velde, M., Vicca, S., Babst, F., Beer, C., Buchmann, N., Canadell, J.G., Ciais, P., Cramer, W. Ibrom, A., Miglietta, F., Poulter, B., Rammig, A., Seneviratne, S.I., Walz, A., Wattenbach, M., Zavala, M.A., Zscheischler, J., 2015. Effects of climate extremes on the terrestrial carbon cycle: concepts, processes and potential future impacts. Glob. Chang. Biol. 12:28612880. https://doi.org/10.1111/gcb.12916.

Futter, M., Butterfield, D., Cosby, B., Dillon, P., Wade, A., Whitehead, P., 2007. Modeling the mechanisms that control in-stream dissolved organic carbon dynamics in upland and forested catchments. Water Resour. Res. 43, W02424. https://doi.org/10.1029/ 2006WR004960.

Futter, M., Forsius, M., Holmberg, M., Starr, M., 2009. A long-term simulation of the effects of acidic deposition and climate change on surface water dissolved organic carbon concentrations in a boreal catchment. Hydrol. Res. 40, 291-305.

Futter, M., Erlandsson, M., Butterfield, D., Whitehead, P., Oni, S., Wade, A., 2014. PERSiST: flexible rainfall-runoff modelling toolkit for use with the INCA family of models. Hydrol. Earth Syst. Sci. 10, 8635-8681.

Grayson, R., Kay, P., Foulger, M., Gledhill, S., 2012. A GIS based MCE model for identifying water colour generation potential in UK upland drinking water supply catchments. J. Hydrol. 420-421, 37-45.

Hejzlar, J., Dubrovský, M., Buchtele, J., Růžička, M., 2003. The apparent and potential effects of climate change on the inferred concentration of dissolved organic matter in a temperate stream (the Malše River, South Bohemia). Sci. Total Environ. 310 (1), $143-152$.

Holman, I.P. Brown, C. Janes, V., Sandars, D. 2017. Can we be certain about future land use change in Europe? A multi-scenario, integrated-assessment analysis. Agric. Syst. $151,126-135$

Kalbitz, K., Solinger, S., Park, J.H., Michalzik, B., Matzner, E., 2000. Controls on the dynamics of dissolved organic matter in soils: a review. Soil Sci. 165, 277-304.

Kilb, B., Lange, B., Schaule, G., Wingender, J., Flemming, H.-C., 2003. Contamination of drinking water by coliforms from biofilms grown on rubber-coated valves. Int. J. Hyg. Environ. Health 206 (6), 563-573.

Koehler, A.-K., Murphy, K., Kiely, G., Sottocornola, M., 2009. Seasonal variation of DOC concentration and annual loss of DOC from an Atlantic blanket bog in South Western Ireland. Biogeochemistry 95, 231-242.

Kronholm, S., Capel, P.D., 2012. Concentrations, loads, and yields of organic carbon in streams of agricultural watersheds. J. Environ. Qual. https://doi.org/10.2134/ jeq2012.0045.

Ledesma, J.L.J., Köhler, S.J., Futter, M.N., 2012. Long-term dynamics of dissolved organic carbon: implications for drinking water supply. Sci. Total Environ. 432, 1-11.

Ledesma, J.L.J., Grabs, T., Bishop, K.H., Schiff, S.L., Kohler, S.J., 2015. Potential for long-term transfer of dissolved organic carbon from riparian zones to streams in boreal catchments. Glob. Chang. Biol. 21, 2963-2979.

Liu, W., Xu, X., McGoff, N.M., Eaton, J.M., Leahy, P., Foley, N., Kiely, G., 2014. Spatial and seasonal variation of dissolved organic carbon (DOC) concentrations in Irish streams: importance of soil and topography characteristics. Environ. Manag. 53, 959-967.

Moore, T.R., Pare, D., Boutin, R., 2008. Production of dissolved organic carbon in Canadian forest soils. Ecosystems 11, 740-751.

Moss, R.H., 2007. Improving information for managing an uncertain future climate. Glob. Environ. Chang. 17 (1), 4-7.
Moss, R.H., Edmonds, J.A., Hibbard, K.A., Manning, M.R., Rose, S.K., van Vuuren, D.P., Carter, T.R., Emori, S., Kainuma, M., Kram, T., Meehl, G.A., Mitchell, J.F.B., Nakicenovic, N., Riahi, K., Smith, S.J., Stouffer, R.J., Thomson, A.M., Weyant, J.P., Wilbanks, T.J., 2010. The next generation of scenarios for climate change research and assessment. Nature 463, 747-756.

Murnane, J.G., Brennan, R.B., Fenton, O., Healy, M.G., 2016. Zeolite combined with Alum and Polyaluminum Chloride mixed with agricultural slurries reduces carbon losses in runoff from grassed soil boxes. J. Environ. Qual. https://doi.org/10.2134/ jeq2016.05.0175.

Naden, P., Allott, N., Arvola, L., JarvinenM, Jennings E., Moore, K., et al., 2010. Modelling the effect of climate change on dissolved organic carbon. In: George, D.G. (Ed.), The Impact of Climate Change of European Lakes. Aquatic Ecology Series Amsterdam. Springer, pp. 221-252.

Nash, J.E., Sutcliffe, J.V., 1970. River flow forecasting through conceptual models, part I-a discussion of principles. J. Hydrol. 10, 282-290.

Nolan, P., 2016. Ensemble of regional climate model projections for Ireland. EPA Research Report No. 159. EPA, Wexford.

O'Driscoll, C., Sheahan, J., Renou-Wilson, F., Croot, P., Pilla, F., Misstear, B., Xiao, L., 2018. National scale assessment of total trihalomethanes in Irish drinking water. J. Environ. Manag. 212, 131-141.

Oni, S.K., Futter, M.N., Molot, L.A., Dillon, P.J., 2012. Modelling the long term impact of climate change on the carbon budget of Lake Simcoe, Ontario using INCA-C. Sci. Total Environ. 414, 387-403.

Oni, S.K., Futter, M.N., Buttle, J., Dillon, P.J., 2015a. Hydrological footprints of urban developments in the Lake Simcoe watershed. Canada: a combined paired-catchment and change detection modelling approach. Hydrol. Process. 29, 1829-1843.

Oni, S.K., Tiwari, T., Ledesma, J.L., Ågren, A.M., Teutschbein, C., Schelker, J., Laudon, H., Futter, M.N., 2015b. Local- and landscape-scale impacts of clear-cuts and climate change on surface water dissolved organic carbon in boreal forests. J. Geophys. Res. Biogeosci. 120. https://doi.org/10.1002/2015JG003190.

Regnier, P., Friedlingstein, P., Ciais, P., Mackenzie, F.T., Gruber, N., Janssens, I.A., Laruelle, G. G., Lauerwald, R., Luyssaert, S., Andersson, A.J., Arndt, S., 2013. Anthropogenic perturbation of the carbon fluxes from land to ocean. Nat. Geosci. 6 (8), 597-607.

Rounsevell, M.D.A., Reginster, I., Araújo, M.B., Carter, T.R., Dendoncker, N., Ewert, F., House, J.I., Kankaanpaa, S., Leemans, R., Metzger, M.J., Schmit, C., Smith, P., Tuck, G., 2006. A coherent set of future land use change scenarios for Europe. Agric. Ecosyst. Environ. 114, 57-68.

Ryder, E., de Eyto, E., Dillane, M., Poole, R., Jennings, E., 2014. Identifying the role of environmental drivers in organic carbon export from a forested peat catchment. Sci. Total Environ. 490, 28-36.

Sokal, R.R., Rohlf, F.J., 1969. Biometry: The Principles and Practice of Statistics in Biological Research. W. H. Freeman, p. 776.

Toner, P., Bowman, J., Clabby, K., Lucey, J., McGarrigle, M., Concannon, C., Cleneghan, C., Cunningham, P., Delaney, J., O'Boyle, S., MacCarthaigh, M., Craig, M., Quinn, R., 2005. Water Quality in Ireland 2001-2003. Environmental Protection Agency, Wexford.

Tunaley, C., Tetzlaff, D., Lessels, J., Soulsby, C., 2016. Linking high-frequency DOC dynamics to the age of connected water sources. Water Resour. Res. 52, 5232-5247.

van Vuuren, D.P., de Vries, B., Beusen, A., Heuberger, P.S.C., 2008. Conditional probabilistic estimates of 21st century greenhouse gas emissions based on the storylines of the IPCC-SRES scenarios. Glob. Environ. Chang. Hum. Policy Dimens. 18, 635-654.

Wellock, M.L., LaPerle, C.M., Kiely, G., 2011a. What is the impact of afforestation on the carbon stocks of Irish mineral soils? For. Ecol. Manag. 262, 1589-1596.

Wellock, M.L., Reidy, B., Laperle, C.M., Bolger, T., Kiely, G., 2011b. Soil organic carbon stocks of afforested peatlands in Ireland. Forestry 84 (4), 441-451.

Whitehead, P.G., Wilby, R.L., Battarbee, R.W., Kernan, M., Wade, A.J., 2009. A review of the potential impacts of climate change on surface water quality. Hydrol. Sci. J. 54 (1), $101-123$. 